\title{
MYCOCHEMICAL ANALYSIS AND PREDICTION OF PLEUROTUS TUBER- REGIUM'S (PLEUROTACEAE) PHARMACOLOGICAL ACTIVITIES, A FOOD AND MEDICINAL FUNGI FROM GABON
}

\author{
Eyi-Ndong H. C. ${ }^{*}$, Iwangou G. ${ }^{2}$ and Orango-Bourdette J. O. ${ }^{3}$ \\ ${ }^{1}$ Institute of Agronomic and Forest Research, BP 2246 Libreville, Gabon \\ ${ }^{2}$ Technological Research Institute, BP 9154 Libreville, Gabon \\ ${ }^{3}$ Masuku University of Science and Technology, BP 942 Franceville, Gabon. \\ *Correspondence E-mail: hugueseyi@yahoo.fr; Tel.: +241066627118; \\ Fax: (+241) 01732578,
}

Cite this article:

Eyi-Ndong H.C., Iwangou G., Orango-Bourdette J.O. (2021), Mycochemical Analysis and Prediction of Pleurotus TuberRegium's (Pleurotaceae) Pharmacological Activities, A Food and Medicinal Fungi from Gabon. African Journal of Biology and Medical Research 4(3), 99-107. DOI: 10.52589/AJBMRMOSHEPZN.

\section{Manuscript History \\ Received: 22 June 2021 \\ Accepted: 14 July 2021 \\ Published: 9 Aug 2021}

Copyright $(9) 2020$ The Author(s). This is an Open Access article distributed under the terms of Creative Commons AttributionNonCommercial-NoDerivatives 4.0 International (CC BY-NC-ND 4.0 ), which permits anyone to share, use, reproduce and redistribute in any medium, provided the original author and source are credited.
ABSTRACT: Pharmaceutical activities of a fungus depend on its bioactive compounds composition. Pleurotus tuber-regium (paleotropical species) is a fungus used in Gabon and throughout tropical Africa for its culinary and medicinal properties. The aim of this study was to predict the therapeutic potential of this species, in particular of its carpophore and its sclerotia, based on the main chemical groups highlighted during the chemical screening of aqueous, hydro-ethanolic and ethanolic extracts. Chemical screening revealed that the three extracts (aqueous, hydro-ethanolic and ethanolic) prepared from the carpophore are rich in total polyphenols, alkaloids, coumarins and proanthocyanidins. Aqueous and hydro-ethanolic extracts are moderately rich in tannins and coumarins while the ethanolic extract is very rich in reducing sugars. About the sclerotia, the three extracts are rich in total polyphenols, alkaloids, reducing sugars and proanthocyanidins. Aqueous and hydro-ethanolic extracts are moderately rich in tannins, total flavonoids and coumarins. The dosage of phenolic compounds carried out on aqueous and hydro-ethanolic extracts confirmed the richness of this fungus in total polyphenols and proanthocyanidins, as well as its deficiency in flavonoids and tannins. The chemical groups thus identified in the carpophore and the sclerotium of P. tuberregium allow to predict its antioxidant, antiallergic, antiplasmodial, anesthetic, analgesic, anticancer, vasodilator, anti-inflammatory and ant-mutagenic activities.

KEYWORDS: Chemical Screening, Bioactive Compounds, Therapeutic Potential, Pleurotus Tuber-Regium, Gabon. 


\section{INTRODUCTION}

Pleurotus tuber-regium (Pleurotaceae) is a species of paleotropical fungus food (Eyi-Ndong, 2009; Eyi-Ndong et al., 2011; De Kesel et al., 2002, 2018) and medicinal (Eyi-Ndong et al., 2020; Mengue-Eyi, 2012; Walleyn \& Rammeloo, 1994) used in Gabon. This fungus, particularly its sclerotia, got great interest to the populations of tropical Africa. In traditional medicine, $P$. tuber-regium is used, in various dosages, to treat common diseases in several African countries (Walleyn \& Rammeloo, 1994). The populations of northern Gabon unanimously use it to treat diseases such as influenza, cough, hernia, scabies, ear infections, genito-anal diseases and navel infection in infants (Eyi-Ndong et al., 2020; Mengue-Eyi, 2012).

In Nigeria, it is used for abdominal pain, constipation, headache, fever, chest pain, smallpox, boils, asthma, control of high blood pressure, nervous disorders and for fetal development during pregnancy (Walleyn \& Rammelo, 1994). In Madagascar, Heim (1935) reported that this fungus is not only used against headaches but also, according to popular beliefs, it protects against certain poisons such as the sap of Cerbera venenifera (Poir.) Steud. (Apocynaceae). He also observed an important use of sclerotia in witchcraft; pregnant women were allowed to enter into the hut where there was a human corpse only after ingesting powder from the sclerotia of $P$. tuber-regium.

Regarding its relative importance and degree of popularity, the study of Eyi-Ndong et al. (2020) among the Fang and Baka ethnic groups found that $P$. tuber-regium is important and popular for both the Fang and the Baka in northern Gabon, with high informant consensus.

This work is part of the knowledge of fungal biodiversity and the enhancement of the traditional knowledge of rural populations in tropical Africa. The objective is to identify the different chemical groups responsible for biological activities in the carpophore and sclerotia of this fungus in order to better understand the reasons for the renewed interest of this fungus in tropical Africa.

\section{MATERIALS AND METHODS}

\section{Harvest and Identification of $\boldsymbol{P}$. tuber-regium}

The mushroom studied was collected in a former plantation in Malibe 2 (Libreville-Gabon). The specimens collected were photographed, described macroscopically, then dried at $60^{\circ} \mathrm{C}$ for 24 hours using a travel dryer. After drying, the mushrooms were described microscopically using an Olympus BX51 microscope equipped with a drawing tube. Microscopic observations of spores, basidia, cystidia, pileus coating and stipe coating were made in Congo Ammoniacal Red. In practice, the structures observed were drawn, their dimensions were measured and compared with the descriptions appearing in reference works (mainly "Illustrated Flora of Central African Mushrooms", "Iconographic Flora of Congo Mushrooms", "Fungus Flora of Tropical Africa", Eyi-Ndong et al. (2011) and the protologues published in various mycological journals). For the description of the spores, the symbol Q $=\mathrm{L} / 1$ represents the length to width ratio of the spores. Measurements of spores, basidia and cystidia were made using the software, Olympus Soft Imaging Solutions $\mathrm{GmbH}$; this software was installed in a computer connected to the microscope. The average value of $\mathrm{Q}$ retained for each species was calculated on a sample of at least twenty spores (Eyi-Ndond et al., 2011). 


\section{Chemical Analysis}

\section{Preparation of Mushroom Extract}

The extracts of the carpophore and the sclerotia were prepared separately. A water-ethanol extract $(50 / 50 \mathrm{v} / \mathrm{v})$, an ethanol extract $\left(90^{\circ}\right)$ and a water extract were prepared from the dry powder of the carpophore and the sclerotia of P. tuber-regium. $500 \mathrm{~mL}$ of each solvent or mixture of solvents were pour into Erlenmeyer containing $50 \mathrm{~g}$ of mushroom powder and left stirring at room temperature $\left(25^{\circ} \mathrm{C}\right)$ for 24 hours. Each extract was filtered using Whatman No. 1 filter paper and the solvents were completely removed at low pressure with a rotary evaporator (Büchi, Labortechnik, Switzerland). The extracts were then concentrated, lyophilized and stored at $4^{\circ} \mathrm{C}$ until analysis.

\section{Qualitative Analysis}

Chemical screening was carried out on each extract in order to highlight the different main chemical groups (Ciulei, 1964). The extracts of P. tuber-regium were analyzed for their classes of bioactive compounds using standard procedures with small modifications (Ciulei, 1964). The extracts were tested qualitatively for the presence of chemical constituents such as tannins, terpenes, saponins, flavonoids, cardiac glycosides, coumarins, alkaloids, anthraquinones and reducing sugar. For gallic tannins, $2 \mathrm{~mL}$ of $1 \%$ ferric chloride solution was added to $2 \mathrm{~mL}$ of the filtrate (Stiasny's test). Dark-greenish coloration indicated their presence. For catechic tannins, $2 \mathrm{~mL}$ of a solution of hydrochloric n-butanol was added to $2 \mathrm{~mL}$ of filtrate, and then heated in a water bath for 5 to 10 minutes (Bate-Smith's test). Intense red coloration indicated the presence of the catechin tannins. For total flavonoids and anthocyanins, $1 \mathrm{~mL}$ of the $\mathrm{NaOH}$ was added to $2 \mathrm{~mL}$ of the filtrate; then, $1 \mathrm{~mL}$ of sulfuric acid was added to the mixture. A dark color after adding acid indicated the presence of flavonoids; the color changing to purple after addition of $\mathrm{NaOH}$ indicated the presence of anthocyanins. To test the cyanidin presence, to 2 $\mathrm{mL}$ of the filtrate was added hydrochloric alcohol and some magnesium strips. A rose-orange effervescence showed the presence of flavones; a rose-purplish color indicated the presence of flavanones and red denoted the presence of flavanols. The Folin's test was applied to determine polyphenol contents. $1 \mathrm{~mL}$ of the Folin reagent was added to $2 \mathrm{~mL}$ of the filtrate. After 5 minutes of incubation at $25^{\circ} \mathrm{C}, 1 \mathrm{~mL} \mathrm{NaOH}$ was added. Dark green coloration indicated the presence of polyphenols. For coumarins, $2 \mathrm{~mL}$ of filtrate combined with $2 \mathrm{~mL}$ of $\mathrm{NH}_{4} \mathrm{OHthen}$, looking at UV lamps (366 nm). The fluorescence presence indicated the presence of coumarins. A rose-pink color of the solution after adding $2 \mathrm{~mL} \mathrm{NH} 4 \mathrm{OH}$ solution into $2 \mathrm{~mL}$ of the filtrate (Borntrager's test) indicated the presence of anthraquinones. For alkaloids, some drops of sulfuric Dragendorff's reagent were added to $2 \mathrm{~mL}$ of the filtrate.

Orange precipitate formed showed the presence of alkaloids. To determine cardiac glycosides and terpenes, tests such as Salkowski's and Lieberman's test were applied; $2 \mathrm{~mL}$ of concentrated $\mathrm{H}_{2} \mathrm{SO}_{4}$ were added to $2 \mathrm{~mL}$ of filtrate. A reddish-brown ring indicated the presence of steroid, an aglycone part of the cardiac glycoside (Salkowski's test). Another part of the filtrate $(2 \mathrm{~mL})$ was added with $2 \mathrm{~mL}$ of acetic anhydride and cooled well in ice, and concentrated $\mathrm{H}_{2} \mathrm{SO}_{4}(2$ $\mathrm{mL}$ ) was carefully added. A color change from blue to green indicated the presence of terpenes (Lieberman's test). Saponins were determined through a frothing test. The filtrate was vigorously shaken. Frothing which persisted on warming for about 15 minutes indicated the presence of saponins. For reducing sugars, equal volume of Fehling's A and Fehling's B reagents were taken in equal quantities. 


\section{Total Phenolic Content}

The total phenolic content of the water-ethanol and the ethanol extract was determined according to the Folin-Ciocalteu method (Singleton et al., 1999) using gallic acid as standard (Obame-Engonga et al., 2017). Absorbance was measured at $735 \mathrm{~nm}$ using a multi-well plate reader ( $\mu$ Quant Bio-Tek Instrument Inc., USA). All analyses were carried out in triplicate and the results (mean of the analysis in triplicate) were expressed in gallic acid equivalent per gram of lyophilized sample (GAE / mg).

\section{Total Flavonoid Content}

The total flavonoid content was determined by colorimetric aluminum chloride $\left(\mathrm{AlCl}_{3}\right)$ assay method (Quettier-Deleu et al., 2000) adapted to a 96-well plate, using quercetin as standard (Sima et al., 2016). Total flavonoid content was expressed in quercetin equivalents in milligrams per gram sample (EQ)/ mg of extract (analysis average in triplicate).

\section{Tannin Content}

The reference method by Sima-Obiang was used to determine the tannin content (Sima-Obiang et al., 2017). Absorbance was measured at $525 \mathrm{~nm}$ and tannic acid was used as a standard. The tannin contents were expressed in mg of tannic acid equivalent (TAE)/100 g of extract.

\section{Proanthocyanidin Content}

The method consists of proanthocyanidins hydrolysis in a hot acid-alcohol medium into anthocyanidins. This method makes it possible to take into account all the units of flavan-3-ols constituting the polymers (Sima-Obiang et al., 2017). The assay was carried out by mixing 50 $\mu \mathrm{L}$ of the extract with $700 \mu \mathrm{L}$ of HCl-butanol solution at $30 \%$ (v/v). The mixture was placed in a hermetically sealed $1.5 \mathrm{~mL}$ Eppendorf tube and vortexed for 1 minute. The tube was then heated for 2 hours at $100^{\circ} \mathrm{C}$. After cooling, $200 \mu \mathrm{L}$ aliquots were placed into a 96-well plate and the absorbance was read at $550 \mathrm{~nm}$. Apple procyanidins $(\mathrm{DP} \approx 7.4)$ treated as mentioned above were used as the standard. The results were expressed in apple procyanidin equivalents (APE).

\section{Statistical Analysis}

Data were expressed as the mean \pm standard deviation (SD) of three independent experiments and analyzed using one-way analysis of variance and Student's t-test. Values of $p<0.05$ were considered to be statistically significant.

\section{RÉSULTATS ET DISCUSSION}

\section{Studied Mushroom}

The species studied was identified as $P$. tuber-regium This saprotrophic species grows in dense humid forests, in open forests, or in plantations. P. tuber-regium was harvested in a plantation of Malibé 2 at $172 \mathrm{~m}$ above sea level. The geographical coordinates are $0^{\circ} 34^{\prime} 0^{\prime \prime} \mathrm{N}$ and $9^{\circ} 27^{\prime} 0^{\prime \prime}$. 
African Journal of Biology and Medical Research

ISSN: 2689-534X

Volume 4, Issue 3, 2021 (pp. 99-107)

www.abjournals.org

\section{Chemical Groups Content}

The results of the chemical screening of $P$. tuber-regium extracts (Figure 1) are shown in Table 1 for the carpophore, and in Table 2 for the sclerotia. The choice of solvents is justified by the fact that various organic compounds, including phenolics and flavonoids, have good solubility in them.

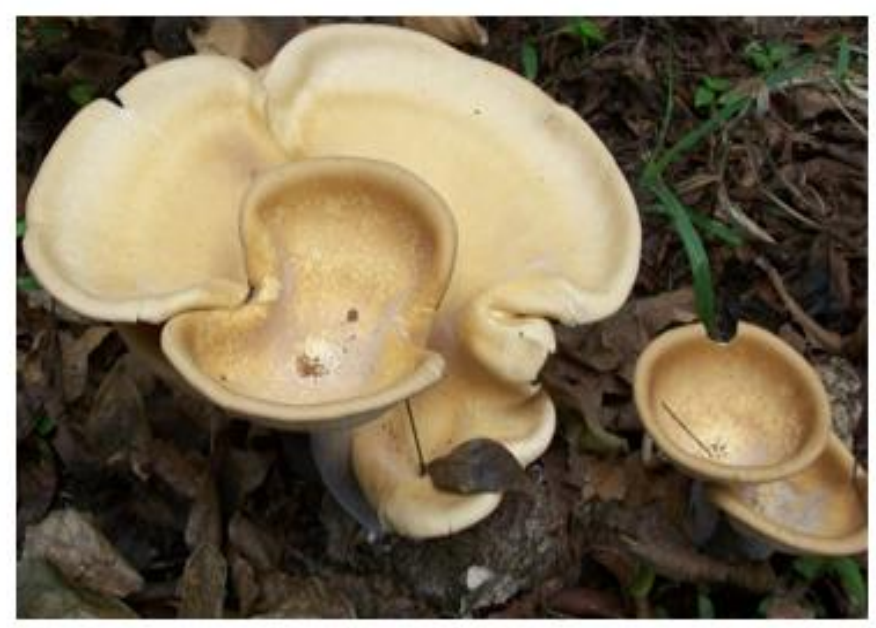

Figure 1. Fruit bodies of $P$. tuber-regium Photograph by Hugues Calixte Eyi Ndong

Table 1: Chemical groups of the carpophore of $P$. tuber-regium extracts

\begin{tabular}{|l|c|c|c|}
\hline \multirow{2}{*}{ Chemical group } & \multicolumn{3}{|c|}{ Extracts } \\
\cline { 2 - 4 } & Aqueous & Hydroalcoholic & Ethanolic $\left(90^{\circ}\right)$ \\
\hline Saponosids & + & + & - \\
\hline Sterols and triterpenes & ++ & ++ & ++ \\
\hline Alkaloids & ++ & ++ & +++ \\
\hline Gallic tannins & + & - & - \\
\hline Catechin tannins & + & + & - \\
\hline Anthraquinones & ++ & + & - \\
\hline Reducing sugars & +++ & - & ++ \\
\hline Total Polyphenols & +++ & ++ & - \\
\hline Total flavonoids & + & + & - \\
\hline Flavonol & - & - & - \\
\hline Flavone & + & - & + \\
\hline Flavanone & + & - & - \\
\hline Coumarins & +++ & ++ & ++ \\
\hline Digitoxin & ++ & - & + \\
\hline Digitoxigenin & ++ & ++ & - \\
\hline Gitoxin & - & + & +++ \\
\hline Gitoxigenin & + & - & - \\
\hline Osse and holosides & +++ & ++ & +++ \\
\hline Anthocyanins & - & - & - \\
\hline Proanthocyanidins & +++ & - & - \\
\hline
\end{tabular}

+++ , very abundant; ++ , abundant; +, not abundant; - , not detected. 
Table 2. Chemical groups of the sclerotum of $P$. tuber-regium extracts.

\begin{tabular}{|l|c|c|c|}
\hline \multirow{2}{*}{ Chemical group } & \multicolumn{3}{|c|}{ Extracts } \\
\cline { 2 - 4 } & Aqueous & Hydroalcoholic & $\begin{array}{l}\text { Ethanolic } \\
\left(90^{\circ}\right)\end{array}$ \\
\hline Saponosids & + & - & - \\
\hline Sterols and triterpenes & + & + & + \\
\hline Alkaloids & ++ & ++ & +++ \\
\hline Gallic tannins & + & + & - \\
\hline Catechin tannins & - & - & - \\
\hline Anthraquinones & - & - & - \\
\hline Reducing sugars & ++ & ++ & ++ \\
\hline Total Polyphenols & ++ & ++ & ++ \\
\hline Total flavonoids & + & + & - \\
\hline Flavonol & - & - & - \\
\hline Flavone & - & - & - \\
\hline Flavanone & - & - & - \\
\hline Coumarins & ++ & ++ & - \\
\hline Digitoxin & - & - & - \\
\hline Digitoxigenin & ++ & ++ & ++ \\
\hline Gitoxin & + & + & + \\
\hline Gitoxigenin & - & - & - \\
\hline Osse and holosides & + & ++ & +++ \\
\hline Anthocyanins & - & - & - \\
\hline Proanthocyanidins & + & ++ & +++ \\
\hline & & & \\
\hline
\end{tabular}

+++ , very abundant; ++ , abundant; + , not abundant; - , not detected.

The choice of the extraction method is a very important parameter to obtain extracts with good yields. The results of our study show that the chosen solvent defines the quantity and quality of the compounds contained in the treated extract. Table 1 shows that the three extracts (aqueous, hydro-ethanolic and ethanolic) prepared from the carpophore of $P$. tuber-regium are abundant in total polyphenols, alkaloids, sterols and triterpene, and digitoxigenin. Proanthocyanidines and oses and holosides are very abundant in aqueous and ethanolic extracts but the proanthocyanidines are respectively absent and abundant in the carpophore and the sclerotum hydro-ethanolic extracts. The aqueous extract is very rich in reducing sugars. Regarding the sclerotia (Table 2), the three extracts prepared from the sclerotia are rich in total polyphenols, alkaloids, reducing sugars and digitoxigenin. Tannins and flavonoids are rare while proanthocyanidins are very abundant in hydro-ethanolic and ethanolic extracts.

The abundance of polyphenols suggests P. tuber-regium antioxidant (Bruneton, 2009), antiallergic (Karou et al., 2007) and antiplasmodial (Casano et al., 2010) properties. Alkaloids give it anesthetic, analgesic, anticancer and vasodilator properties (Bruneton, 2009). It also has some anti-bacterial, anti-plasmodial and anti-inflammatory virtues due to its moderate content of saponosides (Bruneton, 2009). As for the coumarins detected, they give it anti-carcinogenic and ant-mutagenic properties (Ferguson, 2001). 
African Journal of Biology and Medical Research

ISSN: 2689-534X

Volume 4, Issue 3, 2021 (pp. 99-107)

www.abjournals.org

\section{Phenolic groups content}

The phenolic groups content of $P$. tuber-regium are shown in Table 3.

Table 3. Phenolic compounds content of de $P$. tuber-regium extracts

\begin{tabular}{|c|c|c|c|c|c|}
\hline $\begin{array}{l}\text { Part of the } \\
\text { fungus }\end{array}$ & Extraits & $\begin{array}{l}\text { Total phenolic } \\
\text { content (GAE } / \mathrm{mg})\end{array}$ & $\begin{array}{l}\text { Total } \\
\text { flavonoid } \\
\text { content } \\
(\mathrm{EQ} / \mathrm{mg})\end{array}$ & $\begin{array}{l}\text { Total tannin } \\
\text { content } \\
\text { (TAE/mg) }\end{array}$ & $\begin{array}{l}\text { Total } \\
\text { proanthocyanidin } \\
\text { content } \\
(\mathrm{APE} / \mathrm{mg})\end{array}$ \\
\hline & $\mathrm{AQ}$ & $1148,93 \pm 1230,27$ & $337,23 \pm 0,88$ & $\begin{array}{l}187,65 \pm \\
54,75\end{array}$ & $1086 \pm 21,18$ \\
\hline sclerotum & $\mathrm{HE}$ & $1904,56 \pm 1087,79$ & $\begin{array}{l}236,23 \pm \\
33,26\end{array}$ & $\begin{array}{l}400,31 \pm \\
57,74\end{array}$ & $979,47 \pm 360,39$ \\
\hline & AQ & $1742,81 \pm 454,05$ & $\begin{array}{l}325,15 \pm \\
29,27\end{array}$ & $\begin{array}{l}393,46 \pm \\
49,63\end{array}$ & $834,36 \pm 281,26$ \\
\hline Carpophore & HE & $1129,56 \pm 254,82$ & $\begin{array}{l}130,84 \pm \\
40,36\end{array}$ & $\begin{array}{l}398,28 \pm \\
47,43\end{array}$ & $705,11 \pm 363,1$ \\
\hline
\end{tabular}

The dosage of phenolic compounds carried out on the aqueous and hydro-ethanolic extracts (Table 3) confirmed the richness of this fungus in total polyphenols and proanthocyanidins, as well as its deficiency in flavonoids and tannins. These data confirm the anticarcinogenic (Fantini et al., 2015; Ramos, 2008), antioxidant, anti-allergic and antiplasmodial properties of the fungus studied.

The pharmacological properties of $P$. tuber-regium thus identified confirm the legendary importance of this species in certain countries of tropical Africa such as Gabon (Mengue-Eyi, 2014; Eyi-Ndong et al., 2020), Nigeria (Walleyn \& Rammeloo, 1994; Wakefield, 1914) and Zanzibar (Hennings, 1895). This essentially therapeutic interest of P. tuber-regium is certainly linked to the physicochemical composition of its sclerotia. According to Walleyn and Rammeloo (1994), a chromatographic analysis of sclerotia in Nigeria revealed the presence of essential elements for good health, such as carbohydrates-glucose (fuel of cells and main actor in blood sugar regulation), fructose, mannose, galactose, maltose, and sucrose - inositol (group B vitamin involved in growth control and preventing the proliferation of cancer cells), cholesterol, palmitic acid, oleic acid and stearic acid. Also, analysis of the ash revealed the presence of $0.271 \%$ potassium (which directs the hydration of the body's cells) and $0.0039 \%$ sodium (which maintains the acid-base balance of the blood and the isotonicity of the cells).

\section{CONCLUSION}

The present study based on a chemical screening allowed not only the highlighting of numerous bioactive compounds contained in the studied sample, but also the prediction of the therapeutic properties of $P$. tuber-regium. The results of the chemical screening supported by the determination of the phenolic compounds of these extracts showed that it contains phenolic compounds in varying amounts depending on the solvents used. The presence of these compounds makes it possible to predict anesthetic, analgesic, anticancer, antiallergic, antibacterial, anti-inflammatory, antimutagenic, antiplasmodial, vasodilator and especially 
antioxidant properties, which makes this fungus a potential remedy for common diseases such as malaria, bacterial infections, various inflammations and even some forms of cancer.

\section{REFERENCES}

[1]. Antonín, V. Fungus flora of tropical Africa. Meise, Belgium: National Botanic Garden of Belgium.

[2]. Beeli, M and Goossens-Fontana, M. Iconographic flora of the mushrooms of the Congo. Meise, Belgium: National Botanic Garden of Belgium

[3]. Bruneton, J. (2009). Pharmacognosie-phytochimie, plantes médicinales. 4th éd. Paris, France: Lavoisier Techniques and Documentation Médicales Internationales.

[4]. Casano, G., Dumètre, A., Pannecouque, C., Hutter, S., Azas, N and Robin, M. (2010). Anti-HIV and antiplasmodial activity of original flavonoid derivatives. Bioorganic Med Chem., 18(16):6012-23.

[5]. Ciulei, I. (1964). Practical manuals on the industrial utilization of medicinal and aromatic plants. Bucharest, Romania: University of Bucharest.

[6]. De Kesel, A., Codjia, J.T.C and Yourou. S.N. (2002). Guide des champignons comestibles du Bénin, Cotonou République du Bénin, Jardin Botanique National de Belgique et Centre International d'Ecodéveloppement Intégré (CECADI). Impr. CocoMultimédia, 275p.

[7]. Eyi-Ndong, H. C. (2009). Étude des champignons de la forêt dense humide consommés

[8]. par les populations du nord du Gabon. Thèse de Doctorat en sciences biologiques, Université libre de Bruxelles, $271 \mathrm{p}$.

[9]. Eyi-Ndong, H.C., Degreef, J and De Kesel, A. (2011). Champignons comestibles des forêts denses d'Afrique centrale. Taxonomie et identification. ABC Taxa, vol.10.

[10]. Eyi-Ndong, H.C., Mengue Eyi, S., Njouonkou, A.L and Codja, J.T.C. (2020). Contribution à la connaissance des champignons médicinaux du Gabon. Bull Soc Mycol Fr., 133(1-2):159-76.

[11]. Fantini, M., Benvenuto, M., Masuelli, L., Frajese, G. V., Tresoldi, I., Modesti, A and Bei, R. (2015). In vitro and in vivo antitumoral effects of combinations of polyphenols, or polyphenols and anticancer drugs: Perspectives on cancer treatment. International Journal of Molecular Sciences, 16: 9236-9282.

[12]. Ferguson, L.R. (2001). Role of plant polyphenols in genomic stability. Mutation Res., 475(1-2):89-111.

[13]. Heim, R. (1935). L’Olatafa. Arch. mus. nat. hist. nat., sér. 6, 12, p. 549-554.

[14]. Heinemann, P and Rammeloo, J. Illustrated flora of mushrooms of Central Africa. Meise, Belgium: National Botanic Garden of Belgium.

[15]. Hennings, P. (1895). Fungi kameruneneses I. Bot. Jahrb. Syst., 22, p. 72-111.

[16]. Karou, D., Nadembega, W.M.C., Ouattara, L., Ilboudo, D.P., Canini, A., Nikiéma, J.B., Simporé, J., Colizzi, V and Traoré, A.S. (2007). African ethnopharmacology and new drug discovery. Med Arom Plant Sci Biotechnol., 1(1):1-7.

[17]. Mengue-Eyi, S. (2014). Etude ethnomycologique des champignons médicinaux et hallucinogènes du nord du Gabon. Mémoire de master professionnel. Cotonou, Bénin: Université d'Abomey Calavi. 
[18]. Obame-Engonga, L.C., Abdoul-Latif-Fatouma, M., Ondo, J.P., Sima-Obiang, C., Ngoua-Meye-Misso, R.L., Traoré, A and Koudou, J. (2017). Phytochemical screening, antioxidant and antibacterial activities of Guibourtia ehie and Syzygium rowlandii. Int. J. Current Res., 9(8): 56354-60.

[19]. Quettier-Deleu, C., Gressier, B., Vasseur, J., Dine, T., Brunet, C., Luyckx, M and Trotin, F. (2000). Phenolic compounds and antioxidant activities of buckwheat (Fagopyrum esculentum Moench) hulls and flour. J Ethnopharm., 72(1-2):35-42.

[20]. Ramos, S. (2008). Cancer chemoprevention and chemotherapy: Dietary polyphenols and signaling pathways. Molecular Nutrition \& Food Resesearch, 52: 507-526.

[21]. Sima-Obiang, C., Ondo, J.P., Ndong-Atome, G.R., Obame-Engonga, L.C., Djoba, S.J.F and Nsi-Emvo, E. (2016). Phytochemical screening, antioxidant and antimicrobial potential of stem barks of Coula edulis Baill. Pseudospondias longifolia Engl. and Carapa klaineana Pierre from Gabon. Asian Pac. J. Trop. Dis., 6(7):557-63.

[22]. Sima-Obiang, C., Ngoua-Meye-Misso, R.L., Ndong-Atome, G.R., Ondo, J.P., ObameEngonga, L.C and Nsi-Emvo, E. (2017). Chemical composition, antioxidant and antimicrobial activities of stem barks of Englerina gabonensis. Int. J. Phytomed., 9:50110 .

[23]. Singleton, V.L., Orthofer, R and Lamuela-Raventos, R.M. (1999). Analysis of total phenols and other oxidation substrates and antioxidants by means of Folin-Ciocalteu reagent. Methods Enzymol., 299:152-78.

[24]. Wakefield, E. M. (1914). Nigeria fungi. II. Bull. Misc. Inform. Kew, p. 253-261. 